\title{
Dissolved organic matter in Antarctic sea ice
}

\author{
David N. Thomas, ${ }^{1}$ Gerhard Kattner, ${ }^{2}$ Ralph Engbrodt, ${ }^{2}$ Virginia Giannelli, ${ }^{1}$ \\ Hilary Kennedy, ${ }^{1}$ Christian Haas, ${ }^{2}$ Gerhard S. Diegkmann ${ }^{2}$ \\ ${ }^{1}$ School of Ocean Sciences, University of Wales, Bangor, Menai Bridge, Anglesey LL59 5EY, Wales \\ ${ }^{2}$ Alfred Wegener Institute for Polar and Marine Research, Am Handelshafen 12, D-27570 Bremerhaven, Germany
}

\begin{abstract}
It has been hypothesized that there are significant dissolved organic matter (DOM) pools in sea-ice systems, although measurements of DOM in sea ice have only rarely been made. The significance of DOM for ice-based productivity and carbon turnover therefore remains highly speculative. DOM within sea ice from the Amundsen and Bellingshausen Seas, Antarctica, in 1994 and the Weddell Sea, Antarctica, in 1992 and 1997 was investigated. Measurements were made on melted sea-ice sections in 1994 and 1997 and in sea-ice brines in 1992. Dissolved organic carbon (DOC) and dissolved organic nitrogen (DON) concentrations in melted ice cores were up to 1.8 and $0.78 \mathrm{mM}$, respectively, or 30 and 8 times higher than those in surface water concentrations, respectively. However, when concentrations within the brine channel/pore space were calculated from estimated brine volumes, actual concentrations of DOC in brines were up to $23.3 \mathrm{mM}$ and DON up to $2.2 \mathrm{mM}$, although mean values were 1.8 and $0.15 \mathrm{mM}$, respectively. There were higher concentrations of DOM in warm, porous summer second-year sea ice compared with colder autumn first-year ice, consistent with the different biological activity supported within the various ice types. However, in general there was poor correlation between DOC and DON with algal biomass and numbers of bacteria within the ice. The mean DOC/DON ratio was 11, although again values were highly variable, ranging from 3 to highly carbon-enriched samples of 95 . Measurements made on a limited dataset showed that carbohydrates constitute on average $35 \%$ of the DOC pool, with highly variable contributions of $1-99 \%$.
\end{abstract}

\section{INTRODUCTION}

Sea ice provides several habitats that support at times rich and varied biological assemblages (reviewed by Palmisano and Garrison, 1993; Ackley and Sullivan, 1994). Since the early 1980 s, efforts to investigate the biology of sea ice have intensified, and much of the work has focused on the composition, physiology and ecology of the algae that dominate the sea-ice assemblages. There is also a substantial literature on the heterotrophic activity and composition of the microbial network within sea ice (Helmke and Weyland, 1995; Grossmann and others, 1996; and citations therein). Increasingly, studies have concentrated on the physical and chemical limits constraining the biology and how in turn the organisms influence the nature of the ice matrix in which they are contained. High rates of inorganic nutrient remineralization have been measured, or at least implied from measurements of inorganic nitrogen and phosphorus within closed ice. Several studies have endeavoured to relate bacterial activity to algal standing stocks or more directly to primary production taking place within the ice. However, it is surprising that very few studies have been conducted into the link between these two components by measuring the production and fate of dissolved organic matter (DOM). It has long been speculated that levels of DOM must be high within the ice (Grossmann and Dieckmann, 1994; Grossmann and others, 1996; Günther and others, 1999), although very few measurements have actually been made to qualify this (Mel'nikov and Pavlov, 1978; Apollonio, 1980; Bunch and Harland, 1990; Thomas and others, 1995, 1998,
2001; Smith and others, 1997). By default even less work has been conducted into the characterization of the DOM, even in the broadest sense. However, recently Amon and others (2001) have shown a large contribution of neutral sugar and amino acid carbon to total dissolved organic carbon (DOG) in DOM extracted from multi-year Arctic ice. They conclude that this material was freshly produced and of algal origin.

Sources of DOM within sea ice are, as in the open water, excretion of organic matter from all of the biology and release of organic matter on organism death and cell lysis. DOM concentrations can be enhanced by mechanical damage due to the dynamic nature of the brine channel system with changing temperatures (Eicken, 1992; Weissenberger and others, 1992; and citations therein). Of course, during sea-ice formation DOM is also incorporated into the ice matrix from the sea water itself (Haas and others, 1999; Giannelli and others, 2001).

C. Krembs and others (unpublished information, 2000) have shown that sea-ice diatoms release substantial quantities of exopolymeric substances (EPSs) that can alter brine pore structure around diatoms and protect them from ice crystal damage during freezing. These substances can also interconnect pores and may significantly affect the hysteresis of brine pore space and the permeability for solutes and microorganisms. Other ice-active organic substances released by ice diatoms that roughen ice surfaces are proposed to promote binding sites for attached species, or increase light scattering (Raymond and others, 1994).

The magnitude and quality of DOM within the sea-ice matrix is not just of significance to the sea-ice microbial net- 
work, but also to the biology at the ice/water interface. Sea ice can act as a source of DOM to the underlying sea water, supporting heterotrophic activity at the ice/water interface and surface waters. Studies by Krembs and Engel (2001) have shown that ice-locked EPSs are important for the microbiology at the ice/water interface of melting first-year sea ice in the Arctic. Kähler and others (1997) measured variable DOM concentrations in waters underlying sea ice or those influenced by ice melt. They measured at times highly enriched DOC and dissolved organic nitrogen (DON) concentrations, implying that DOM was being released from the ice. This DOM can support bacterial growth, and in experiments Kähler and others (1997) measured the highest bacteria growth rates in DOC-rich melted sea ice as compared to growth rates measured in surface or deep-water samples. The labile nature of the DOM released from the sea ice was investigated, with $40-60 \%$ of the DOG, in excess of deep-water concentrations, being found to be available for bacteria growth.

Giesenhagen and others (1999) also report that DOM released from ice serves as an important input for bacterioplankton. They found that much of this DOM was in a form that was directly taken up by bacteria (e.g. sugars and amino acids), and that the additional dissolved degradable material lowered the turnover of the hydrolysable pool. No similar stimulation was noticed for the nano- and microalgae, although Brandini and Baumann (1997) showed that DOM released from sea ice may significantly enhance algal growth in surface waters. Likewise, Kuosa and others (1992) conclude that DOC from melting ice may be influential during the seeding of sea-ice microbial communities in the water column.

Here we present a compilation of information about the DOC and DON from sea ice that had lasted at least one summer in the Weddell, Bellingshausen and Amundsen Seas, Antarctica. The porous nature of ice in late austral summer or early autumn, coupled with the non-limiting light conditions, means that this is a time when biological activity within the ice will be at a maximum. Subsequently it can be predicted that the production of DOM within the ice will be high, thus playing an important role in the ice biogeochemical cycles.

\section{METHODS}

During the ANT 10/3 expedition of RV Polarstern (April-May 1992; Fig. 1) samples of sea-ice brine were collected from ice floes in the closed pack ice of the southeastern Weddell Sea (see Gleitz and Thomas, 1993; Gleitz and others, 1995). Therefore surface snow and short cores $(30-40 \mathrm{~cm})$ were removed from the top of the floe. The core holes were covered, and after time-spans of minutes up to about 1 hour enough brine had accumulated in the "sack hole" for subsequent analysis. Back on board ship the brines were filtered through precombusted $\left(450^{\circ} \mathrm{C}, 4 \mathrm{~h}\right) \mathrm{GF} / \mathrm{F}$ filters, the filter being retained for chlorophyll $a(\mathrm{Chl} a)$ analysis, and the filtrate acidified and stored in precombusted glass ampoules for later DOC analyses.

InJanuary-February 1994 (ANT 11/3; Fig. 1) ice cores were sampled in the Bellingshausen and Amundsen Seas in areas of dense pack ice (ice cover 10/10). The second- or multi-year ice floes, 1-4 $\mathrm{m}$ thick, were $10-1000 \mathrm{~m}$ in diameter (Haas and others, 1996).

In January-March 1997 (ANT 14/3; Fig. 1) sea-ice cores were collected within the inner pack ice of the southeastern

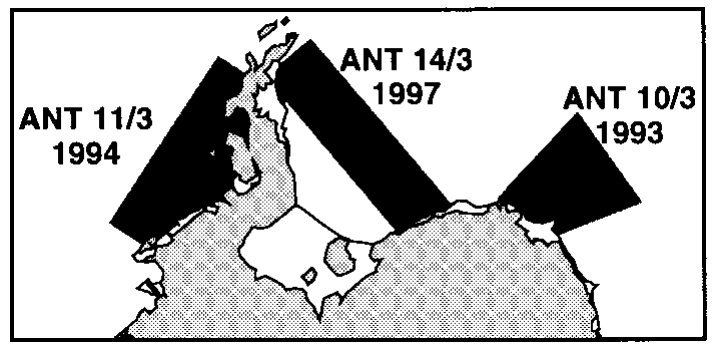

Fig. 1. Regions covered on campaigns during which ice samples for DOM were taken.

Weddell Sea during a first sampling campaign. The ice concentration was $>9 / 10$ and typical floe sizes were 100-500 m. A second period of sampling took place along a transect across the Weddell Sea to a northwesternmost position $\left(66^{\circ} 08^{\prime} \mathrm{S}, 56^{\circ} 09^{\prime} \mathrm{W}\right)$ and back again to the southeast. During this time the floes had diameters of $<100 \mathrm{~m}$, with ice covers <5/10 (Haas and others, 1998).

During the 1994 and 1997 campaigns 10 and 29 ice cores, respectively, were collected with a titanium ice-corer $19 \mathrm{~cm}$ internal diameter). During coring and subsequent handling, care was taken not to contaminate the ice. Immediately after coring, the cores were divided into $10 \mathrm{~cm}$ sections with a clean stainless-steel saw, and these were put into $1 \mathrm{~L}$ opaque PVC containers.

On board ship the ice sections were melted in the containers at $4^{\circ} \mathrm{C}$ in the dark. This process took no longer than $24 \mathrm{~h}$. Due to the porous nature of the ice, the melting periods were often considerably faster. There has been concern that this melting process may lead to elevated concentrations of nutrients and DOC in the meltwater following osmotic shock to organisms and release of internal pools during the rapid changes in salinity (Garrison and Buck, 1986). However, this is not the case in ice samples dominated by diatoms (Thomas and others, 1998), as were the samples presented here, determined after microscopic analyses.

Salinities of melted core sections were measured at room temperature with a conductivity salinometer (WTW, Weilheim, Germany), and then subsamples were filtered through precombusted GF/F filters. Samples for Chl $a$ were collected on filters and stored frozen until analysis in the home laboratories. Filtrates were poisoned with $\mathrm{HgCl}_{2}$ and stored at $4^{\circ} \mathrm{C}$ in $50 \mathrm{~mL}$ polyethylene bottles for $\mathrm{DON}$ analyses. Additional filtrate was stored frozen below $-25^{\circ} \mathrm{C}$ (unpoisoned) in $50 \mathrm{~mL}$ precombusted glass ampoules for DOC determination.

In 1997, before filtration, $20 \mathrm{~mL}$ subsamples were taken and fixed $(0.4 \%$ formaldehyde, final concentration, stored at $4^{\circ} \mathrm{C}$ ). Bacterial cell concentrations were determined using epifluorescence microscopy of DAPI stained samples (Porter and Feig, 1980).

Chl $a$ was determined using a Turner fluorometer (Evans and others, 1987), after extraction overnight in the dark at $4^{\circ} \mathrm{C}$. DON was analyzed following persulphate wet oxidation followed by standard autoanalyzer methods (Kattner and Becker, 1991), and DOC by high-temperature oxidation using an MQ1001 TOC Analyser (Qian and Mopper, 1996), and for $50 \%$ of the 1994 samples a Shimadzu 5000 TOC Analyser.

Total dissolved carbohydrates (TCHO) were measured on some of the 1994 samples using the L-tryptophan/sulphuric acid method on a Technicon Autoanalyser (Eberlein and 
Table 1. The salinity, Chla, DOC and DON content of melted sea-ice core sections collected by standard ice-coring techniques and of sea-ice brines collected by sack-hole sampling

\begin{tabular}{|c|c|c|c|c|c|}
\hline & $\begin{array}{c}\text { Number of } \\
\text { samples }\end{array}$ & Mean & $\begin{array}{c}\text { Mini- } \\
\text { mum }\end{array}$ & $\begin{array}{l}\text { Maxi- } \\
\text { mum }\end{array}$ & Std dev \\
\hline \multicolumn{6}{|l|}{ Brine } \\
\hline \multicolumn{6}{|l|}{ ANT 10/3 1992} \\
\hline Salinity & 8 & 62.04 & 32.8 & 107.8 & 25.2 \\
\hline $\operatorname{Chl} a\left(\mu \mathrm{g} \mathrm{L}^{-1}\right)$ & 8 & 9 & 1 & 18 & 5.4 \\
\hline $\operatorname{DOC}(\mu \mathrm{M})$ & 8 & 523 & 147 & 866 & 207.9 \\
\hline \multicolumn{6}{|l|}{ Melted ice cores } \\
\hline \multicolumn{6}{|l|}{ ANT 11/3 1994} \\
\hline Salinity & 130 & 4.28 & 0.13 & 11.00 & 2.2 \\
\hline Chl $a\left(\mu \mathrm{g} \mathrm{L}^{-1}\right)$ & 132 & 32 & 0 & 378 & 60.0 \\
\hline $\operatorname{DOC}(\mu \mathrm{M})$ & 132 & 109 & 16 & 556 & 83.5 \\
\hline Calculated brine volume (ppt) & 130 & 117 & 4 & 306 & 59.7 \\
\hline DOG in brine $(\mu \mathrm{M})$ & 130 & 1832 & 134 & 23284 & 3510 \\
\hline \multicolumn{6}{|l|}{ ANT 14/3 1997} \\
\hline Salinity & 181 & 6.26 & 0.40 & 17.20 & 3.6 \\
\hline Chl $\left.a(\mu \mathrm{g} \mathrm{L})^{-1}\right)$ & 182 & 38 & 0 & 439 & 79.1 \\
\hline $\operatorname{DOC}(\mu \mathrm{M})$ & 157 & 207 & 16 & 1842 & 239.6 \\
\hline $\operatorname{DON}(\mu \mathrm{M})$ & 176 & 17 & 2 & 78 & 12.9 \\
\hline $\mathrm{DOC} / \mathrm{DON}$ & 149 & 11 & 3 & 95 & 10.1 \\
\hline Calculated brine volume (ppt) & 181 & 172 & 11 & 487 & 102.0 \\
\hline DOG in brine $(\mu \mathrm{M})$ & 154 & 1569 & 124 & 18451 & 2218 \\
\hline DON in brine $(\mu \mathrm{M})$ & 172 & 145 & 8 & 2230 & 220 \\
\hline
\end{tabular}

Notes: Samples were collected in the Amundsen and Bellingshausen Seas in 1994 (from 10 sectioned cores), and in the Weddell Sea in 1992 (8 sackhole samples) and 1997 (from 29 sectioned cores). Equations of Cox and Weeks (1983) with coefficients given by Leppäranta and Manninen (unpublished), assuming a gas volume of $10 \%$ and an isothermal ice temperature of $-1.8^{\circ} \mathrm{C}$, were used to calculate the brine volumes for the 1994 and 1997 melted ice cores.

Hammer, 1980). The sum of mono- and hydrolysable oligoand polysaccharides is determined by this method. All samples were analyzed in duplicate with four glucose and three nitrate standards at the beginning and end of each run.

\section{RESULTS AND DISGUSSION}

This extensive study of DOM in sea ice included samples from diverse ice types in different regions of the Southern Ocean during summer and early autumn, and levels of DOM in sea ice were clearly enriched (Table 1; Figs 2-4). It should be stressed that the 1992 directly sampled brines were from cold, autumn first-year ice, while the 1994 and 1997 samples were mainly collected from warm second-year ice. Clearly the biological activity within the ice and physicochemical histories of the ice will be quite different for the ice collected in different seasons.

The ice in 1997 was generally more porous than in 1994, indicated by the higher ice bulk salinities, up to 17.2 in 1997 compared with 11.4 for 1994 (Fig. 2; Table 1). This is also apparent from the estimated brine volumes which were up to 38\% higher in 1997 compared to 1994 (Table 1). It should be stressed that these calculated brine volumes are only estimates since temperatures of individual samples were not measured. They have been calculated assuming that the ice was isothermal at $-1.8^{\circ} \mathrm{C}$. Equations of Cox and Weeks (1983) with coefficients given by Leppäranta and Manninen (unpublished) for warm ice were used to calculate the brine volumes. The high brine volumes (up to $487 \mathrm{ppt}$ ) clearly indicate the

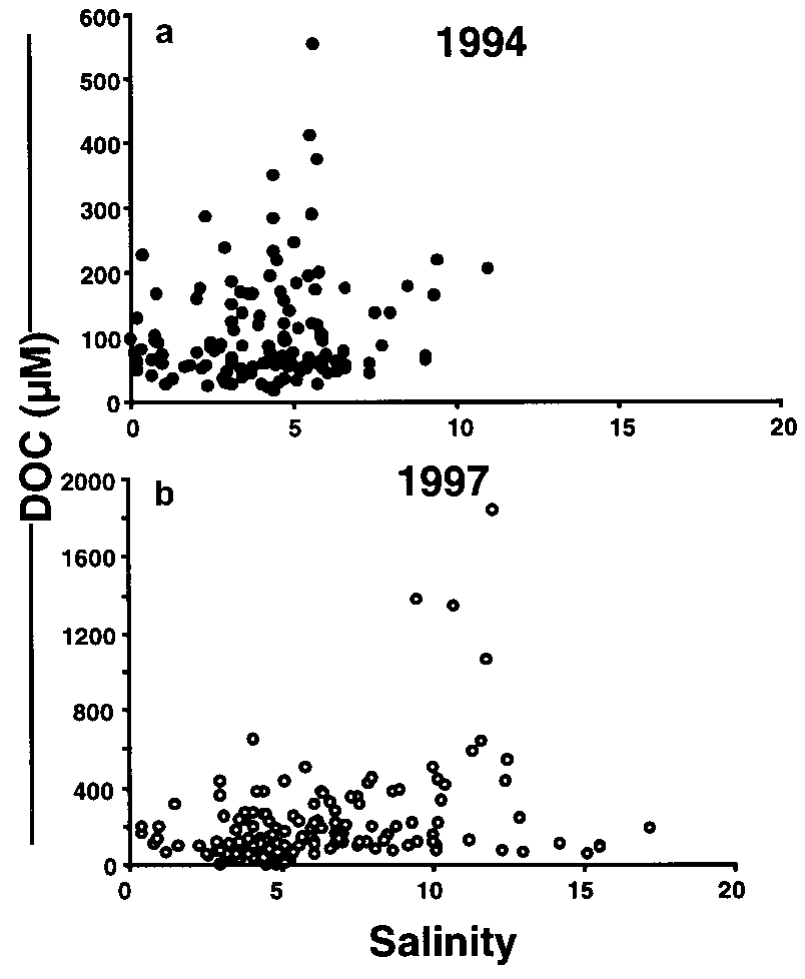

Fig. 2. The relationship between DOC and the bulk salinity of melted ice-core sections collected ( a) in 1994 in the Amundsen and Bellingshausen Seas $(n=132)$ and $(b)$ in 1997 in the Weddell Sea $(n=159)$. Note the different scales for DOC between 1994 and 1997 datasets.

highly porous nature of the late-summer ice sampled in both 1994 and 1997 (mean values 117 and 172 ppt, respectively), and therefore the possibility of dilution of measured brine concentrations of DOM by exchange with sea water.

Concentrations of DOC in ice-core segments sampled in 1994 and 1997 (Fig. 2) were up to 30 times greater than the typical maximum values for Antarctic surface water which are 40-60 $\mu \mathrm{MC}$ (Kähler and others, 1997; Wedborg and others, 1998). At one station values of $180 \mu \mathrm{M} \mathrm{C}$ were recorded in waters associated with sea ice (Kähler and others, 1997), and there is a unique report of values up to $700 \mu \mathrm{MC}$ in the Polar Front Zone (Dafner, 1992). Likewise the sea-ice samples in 1997 were enriched in DON, with measurements up to 8 times those of typical surface waters values, which are 3$10 \mu \mathrm{M} \mathrm{N}$ (Lara and Kattner, 1994; Kähler and others, 1997).

The mean and maximum DOC concentrations were considerably higher in the 1997 samples, while minimum concentrations were lowest in 1997 compared to 1994 values. The highest DOC concentrations were found at different salinities in 1994 and 1997. In 1994 the highest DOC was measured at a salinity of 5.6 (calculated brine volume $153 \mathrm{ppt}$ ), a less porous ice than in 1997 when the highest DOC concentrations were found at salinities of 9.5-12 (respective calculated brine volumes $262-334 \mathrm{ppt}$ ).

Mean Chl $a$ concentrations for both the 1994 and 1997 campaigns were similar, whereas the mean DOC concentrations in 1997 were twice those measured in 1994 (Table 1; Fig. 3). In 1997 the highest DOC values were associated with the greater Chl $a$ values, although even for these high-biomass samples relatively low DOC values were also recorded. In 1994 the highest DOG values were not associated with the higher Chl $a$ ice samples (Fig. 3). An obvious poor correlation between Chl $a$ and DOC does caution against concluding that 


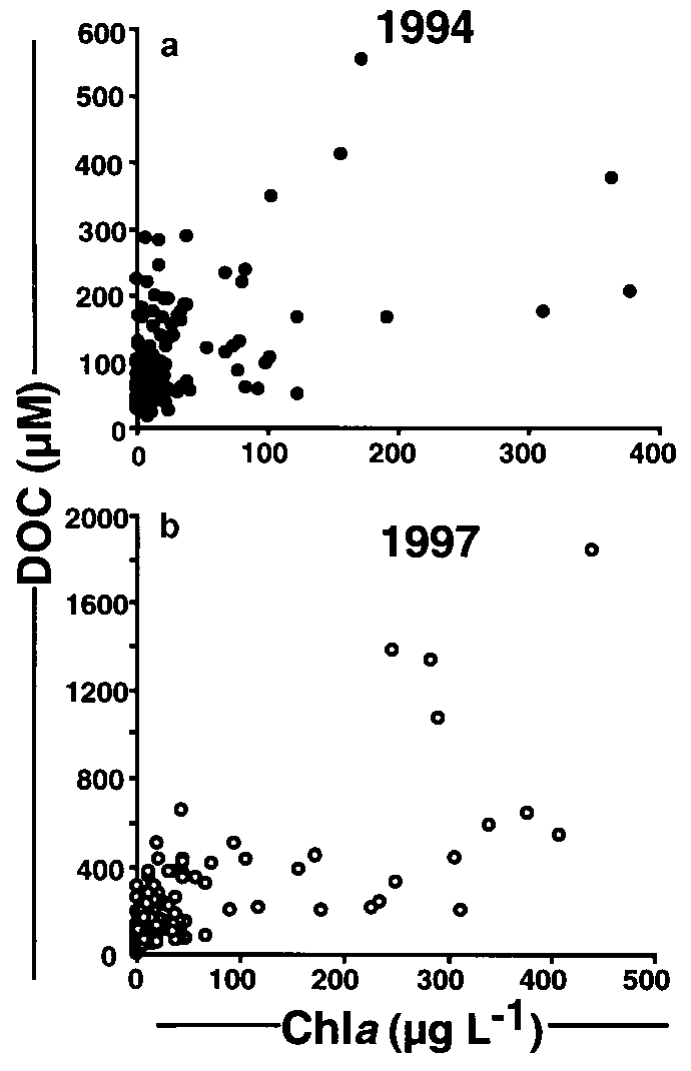

Fig. 3. The relationship between DOC and Chla in melted icecore sections collected (a) in 1994 in the Amundsen and Bellingshausen Seas $(n=132)$ and (b) in 1997 in the Weddell Sea $(n=159)$. Note the different scales for DOC and Chla between 1994 and 1997 datasets.

the DOC originates mainly from ice algae, or at least healthy algae. This contrasts with the findings of Smith and others (1997) who conclude that DOC in the bottom ice of annual sea ice in northern Japan and the Canadian high Arctic is strongly correlated with $\mathrm{Chl} a$, and hence is algal-derived. However, as has been stated before, the sources of DOM within the ice are many and varied. The DOM sampled may have been concentrated by physical rather than biological processes or may be a legacy of previous biological activity where Chl $a$ has degraded but DOC has not been affected. This is reflected in samples having DOG values up to $500 \mu \mathrm{MC}$ with Chl $a$ concentrations close to zero (Fig. 3).

The brines collected by sack-hole sampling in 1992 contained high DOG values (Table 1) with a mean value of $>320 \mu \mathrm{M}$, even though these brine samples had much lower Chl $a$ concentrations than the bulk melted ice cores (Table 1). The minimum DOC value in the brines was also $>130 \mu \mathrm{M}$ higher than the minimum in the other ice samples. To further understand the differences between the melted icecore samples and the limited directly sampled brines, it is useful to consider the estimates of DOC and DON concentrations in the brine, based on the calculated brine volumes for the bulk ice samples (Table 1). It is valid to do this because conservative enrichment of diatom-derived DOM in sea-ice brines similar to that for inorganic nutrients during freezing has been demonstrated by Haas and others (1999) and Giannelli and others (2001).

Estimated brine concentrations were mean values of DOC of 1.8 and $1.5 \mathrm{mM}$ for 1994 and 1997 with maximum values reaching 23.3 and $18.5 \mathrm{mM}$, and mean DON values of

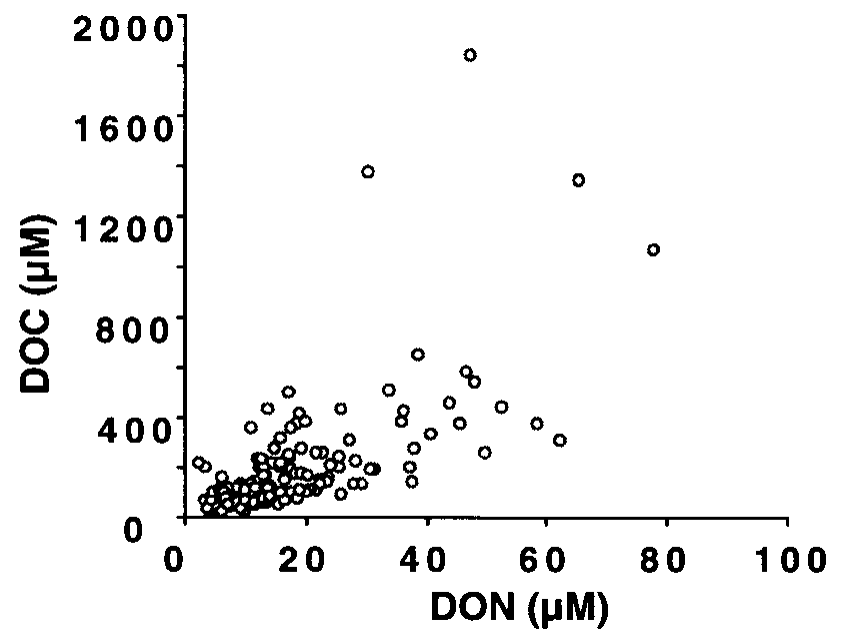

Fig. 4. The relationship between DOC and DON in melted ice-core sections collected in the Weddell Sea in 1997 ( $n=$ 157). Linear regression analysis of the data gives the following relationship: $y=12 x-16.7 ; R^{2}=0.44, p<0.001$.

$0.15 \mathrm{mM}$ and maximum of $2.2 \mathrm{mM}$ in 1997 (Table 1). These are very much greater than in the directly sampled brines from 1992, a better reflection of the obvious differences in biology. However, it is realized that sack-hole sampling does not realistically sample the particulate phase which is mostly attached to the ice matrix and will be underestimated in the sampled brines.

These calculated concentrations of DOG and DON, together with the directly sampled high DOC concentrations in the sack-hole brines, clearly indicate that sea-ice brines are enriched in DOM to a degree not even speculated before. Such high concentrations of DOM within sea-ice brines have profound implications for future work on the microbiology and biogeochemistry of sea ice, and the interpretation of previous works where estimates of DOM within sea ice have only been speculated. These findings are timely and coincide with the complementary work of C. Krembs and others (unpublished information, 2000) who have combined measurements of organic polymers in sea ice with new microscopic techniques (Junge and others, 2001) to investigate bacteria and algae within sea ice. They have clearly shown that substantial amounts of polymers are released into the brine channel system, and they even speculate that brine viscosity may be increased to such a degree that brine transport within sea ice may be altered.

Although not shown, the relationships between DON and Chl $a$ as well as salinity showed similar scattering to DOC, which is the result of a close correlation $(p<0.001)$ between DOC and DON (Fig. 4). Despite the correlation, there was still a large range of DOC/DON ratios. Especially in the samples with DOG values $>800 \mu \mathrm{MC}$ the DOM was highly carbon-enriched, resulting in DOC/DON ratios up to 95 (Table 1). The mean DOC/DON ratio was 11. Thomas and others (1995) measured similar ratios within winter Arctic ice, with mean values of cores ranging from $17 \pm 4$ to $54 \pm 41$. Unlike the present study, a lack of correlation between DOC and DON in that Arctic ice led the authors to conclude that different processes, or an uncoupling of carbon and nitrogen metabolism, were determining the concentrations of DOC and DON. Bulk open-water values usually range between 10 and 25 (Williams and Druffel, 1988), although Kähler and 


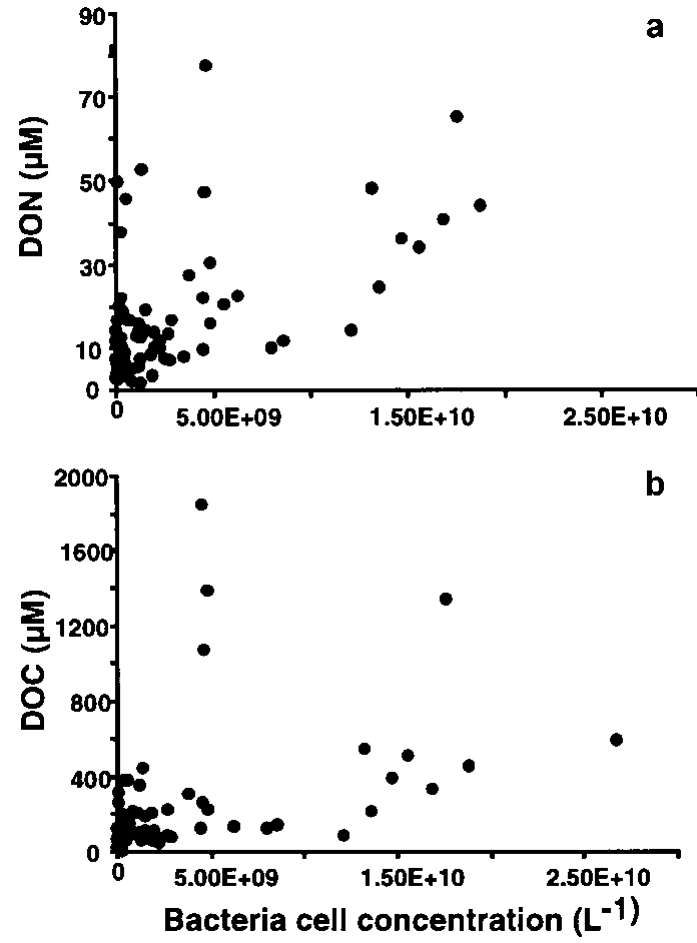

Fig. 5. The relationships of DON ( a) and DOC (b) with bacteria concentration in melted ice-core sections collected in the Weddell Sea, 1997.

others (1997) did measure unusual DOC/DON ratios in Antarctic surface waters between 4 in deep and 8 in surface waters. Accumulation of carbon-rich DOM following algal blooms is discussed by Williams (1995) who attributes accumulation of carbon to inorganic nitrogen limitation. However, in the ice, high algal biomass similar to that reported here is often associated with little or no dissolved inorganic nitrogen depletion (Thomas and others, 1998, and citations therein). In addition, Thomas and others (2001) report DOC/DON ratios of 8 (range 2-20) in platelet ice and 21 in open water (range 15-27) where the ice habitat was more reduced in dissolved inorganic nitrogen than the open water.

In the same way that Chla concentrations were not tightly coupled with DOC and DON concentrations, as might be expected if autotrophic production was a significant source of DOG, bacterial abundance was not correlated with DOC or DON concentrations in the 1997 samples (Fig. 5). The bacterial numbers above $1 \times 10^{10}$ cells $\mathrm{L}^{-1}$ are high for sea ice and similar to those recorded by Grossmann and others (1996), which were some of the highest recorded in sea ice. It is reasonable to speculate that these very high bacterial cell concentrations were a result of the high DOM loading in the ice. However, the relationship between DOM and bacteria is not straightforward. The sampling strategy employed only allows for a snapshot of the conditions and does not allow an historical development of the biological and chemical interactions to be deduced. More systematic investigations, similar to those of Kähler and others (1997) for open waters, that couple measurements of bacterial activity with characterization of DOM are called for, together with time course measurements within closely defined ice habitats. These rate measurements must be made in conjunction with investigations into autotrophic production if the link between DOM production and heterotrophic activity is to be made (cf.

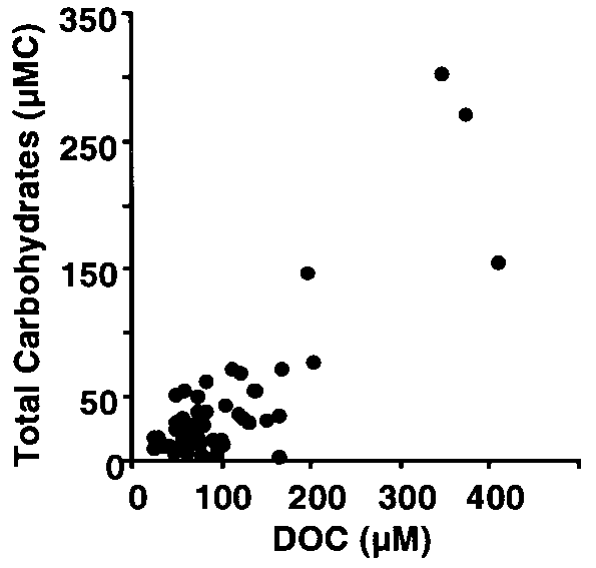

Fig. 6. Relationship between the total carbohydrate concentration and DOC in melted ice-core sections collected in the Amundsen and Bellingshausen Seas, $1994(n=56)$. Linear regression analysis of the data gives the following relationship: $y=0.61 x-21.8 ; R^{2}=0.71, p<0.001$.

Grossmann and Dieckmann, 1994; Gleitz and others, 1996; Grossmann and others, 1996).

There was a significant correlation $(p<0.001)$ between the TCHO concentrations and DOG in the 1994 samples (Fig. 6). The mean percentage contribution of TCHO to the DOC carbon pool was $36 \% \pm 23$ (range 1-99\%). As with DOC, there was no obvious trend of TCHO with either salinity or Chl $a$ in the ice. The mean percentage total carbohydrate content of DOC falls well within the range 10-46\% measured by Pakulski and Benner (1994) in a range of oceanic waters.

The composition of the DOM in the ice should reflect the composition of the dominant organisms, although this will be masked by the release of extracellular products such as polysaccharides and ice-active substances (Raymond and others, 1994; Krembs and others, 2000). Numerous studies have investigated the chemical composition of sea-ice algae (Thomas and Gleitz, 1993, and citations therein), and high allocation of photoassimilated carbon into the lipid $(>70 \%)$ and polysaccharide $(>60 \%)$ fractions of cells has been measured. Thomas and Gleitz (1993) investigated two common ice algae under various temperature and salinity regimes and found typical distributions of carbon as follows: polysaccharides $11-49 \%$, low molecular weight compounds $30-60 \%$, lipids $7-23 \%$ and proteins $12-30 \%$. In particular, as a response to increased salinities in sea ice, enhanced production of intracellular organic osmolytes such as amino acids (e.g. proline) or small carbohydrates (e.g. mannitol) are to be expected. The nature of DOM produced within sea ice is therefore going to be highly variable, and highly dependent on the extremes in the physical and chemical nature of the ice. This is likely to confer on DOM produced within ice a rather different chemistry to that in open waters. This is one reason why simple extrapolation of heterotrophic microbial processes in polar seas to sea ice is flawed since the nature of the DOM in the two systems is dissimilar.

An intriguing question that arises when considering DOM in ice is the extent to which photochemical processes alter the lability of DOM. Photoxidation of high-molecularweight DOM to form biologically labile organic products in open waters is an important feature of organic matter cycling (Mopper and others, 1991; Herndl and others, 1993). The im- 
portance of the different photoreactivities of DOC and DON has been highlighted by Bertilsson and others (1999). Ultraviolet (UV) light does penetrate sea ice (Perovich, 1993, and citations therein), and reliable evidence of UV-B-induced damage to under-ice algal communities is reported (Prézelin and others, 1998). Although UV transmission is greatly attenuated by snow cover, it is likely that at certain times of the year photochemical processes will induce changes in the carbon and nitrogen pools within the ice. This is particularly true in late summer, when snow is thin and superimposed ice may attenuate UV-B only poorly.

The nature of DOM in the ice is clearly highly diverse, as indicated by the large range in DOC/DON ratios and the changing carbohydrate contribution to the DOC pool. This variability points to more systematic studies being called for since our understanding of the nature of the DOM is probably the key to understanding the dynamics of carbon and nitrogen cycling within sea ice, and therefore the role of sea ice in the overall biogeochemical cycling of Polar Oceans. To this end, bacterial growth experiments linked to concurrent analyses of the chemical composition of DOM, such as those of Amon and others (2001), are called for. If we are to comprehend the complexity of biogeochemical cycles with sea ice, it is imperative that the next generation of investigations are truly multidisciplinary, fully integrating the biology and chemistry together with the physics of sea ice.

\section{ACKNOWLEDGEMENTS}

We would like to thank the captain and crew of RV Polarstern and the pilots and crew of the Wasserthal helicopter service. We thank M. Stürcken-Rodewald and C. Harms of the Alfred Wegener Institute, Bremerhaven, and C. Castellani, A. Ross andT. Bentley of the University of Wales, Bangor, for excellent technical assistance. The work was partially funded by the Natural Environment Research Council (GT9/2894, GR9/ 3309), British Council/Deutscher Akademischer Austauschdienst (Academic Research Collaboration Programme) and the Nuffield Foundation.

\section{REFERENGES}

Ackley, S. F. and C.W. Sullivan. 1994. Physical controls on the development and characteristics of Antarctic sea ice biological communities - a review and synthesis. Deep-Sea Res., 41 (10), Part 1, 1583-1604.

Amon, R. M.W., H.-P. Fitznar and R. Benner. 2001. The relationship between bioreactivity, chemical composition, and diagenetic state of marine dissolved organic matter during bacterial degradation. Limnol. Oceanogr., 46(2), 287-297.

Apollonio, S. 1980. Microflora of Arctic sea ice. National Geographic Society Research Reports, 12(1), 13-20.

Bertilsson, S., R. Stepanauskas, R. Cuadros-Hansson, W. Graneli, J. Wikner and L. Tranvik. 1999. Photochemically induced changes in bioavailable carbon and nitrogen pools in a boreal watershed. Aquat. Microb. Ecol., 19 (1), 47-56.

Brandini, F. P. and M. E. M. Baumann. 1997. The potential role of melted "brown ice" as sources of chelators and ammonia to the surface waters of the Weddell Sea, Antarctica. Proc. NIPR Symp. Polar Biol. 10, 1-13.

Bunch, J. N. and R. C. Harland. 1990. Bacterial production in the bottom surface of sea ice in the Canadian subarctic. Can. 7. Fish. Aquat. Sci., 47(10), 1986-1995.

Cox, G. F. N. and W. F. Weeks. 1983. Equations for determining the gas and brine volumes in sea-ice samples. f. Glaciol., 29(102), 306-316.

Dafner, E.V. 1992. Dissolved organic carbon in waters of the Polar Frontal Zone of the Atlantic Antarctic in the spring-summer season of 19881989. Mar. Chem., 37(3-4), 275-283.

Eberlein, K. and K. D. Hammer. 1980. Automatic determination of total carbohydrates in seawater. Fresenius' f. Anal. Chem., 301(1), 17-19.

Eicken, H. 1992. The role of sea ice in structuring Antarctic ecosystems. Polar
Biol., 12(1), 2-13.

Evans, C. A., J. E. O'Reilly and J. P. Thomas. 1987. A handbook for the measurement of chlorophyll a and primary production. Biological investigations of marine Antarctic systems and stocks. College Station, TX, Texas A \& M University. (BIOMASS 8.)

Garrison, D. L. and K. R. Buck. 1986. Organism losses during ice melting: a serious bias in sea ice community studies. Polar Biol., 6(4), 237-239.

Giannelli, V., D. N. Thomas, H. A. Kennedy, G. Kattner, G. S. Dieckmann and C. Haas. 2001. Behaviour of dissolved organic matter and inorganic nutrients during experimental sea-ice formation. Ann. Glaciol., 33 (see paper in this volume).

Giesenhagen, H. C., A. E. Detma, J. de Wall, A. Weber, R. Gradinger and F. J. Jochem. 1999. How are Antarctic planktonic microbial food webs and algal blooms affected by melting of sea ice? Microcosm simulations. Aquat. Microb. Ecol., 20(2), 183-201.

Gleitz, M. and D. N. Thomas. 1993. Variation in phytoplankton standing stock, chemical composition and physiology during sea-ice formation in the southeastern Weddell Sea, Antarctica. 7. Exp. Mar. Biol. Ecol., $\mathbf{1 7 3}(2), 211-230$

Gleitz, M., M. M. R. van der Loeff, D. N. Thomas, G. S. Dieckmann and F. J. Millero. 1995. Comparison of summer and winter inorganic carbon, oxygen and nutrient concentrations in Antarctic sea ice brine. Mar. Chem., 51 (2), 81-91.

Gleitz, M., S. Grossmann, R. Scharek and V. Smetacek. 1996. Ecology of diatom and bacterial assemblages in water associated with melting summer sea ice in the Weddell Sea, Antarctica. Antarct. Sci., 8(2), 135-146.

Grossmann, S. and G. S. Dieckmann. 1994. Bacterial standing stock, activity, and carbon production during formation and growth of sea ice in the Weddell Sea, Antarctica. Appl. Environ. Microbiol., 60(8), 2746-2753.

Grossmann, S., K. Lochte and R. Scharek. 1996. Algal and bacterial processes in platelet ice during late austral summer. Polar Biol., 16 (8), 623-633.

Günther, S., M. Gleitz and G. S. Dieckmann. 1999. Biogeochemistry of Antarctic sea ice: a case study on platelet ice at Drescher Inlet, Weddell Sea. Mar. Ecol. Prog. Ser., 177 (1), 1-13.

Haas, C., H. Rebhan, D. N. Thomas and T. Viehoff. 1996. Sea ice. In Miller, H. and H. Grobe, eds. The Expedition ANTARKTIS-XI/3 of RV Polarstern in 1994. Bremerhaven, Alfred Wegener Institute for Polar and Marine Research, 29-43. (Report 188/96.)

Haas, C., D. N. Thomas, M. Steffens and J. Bareiss. 1998. Physical and biological investigations of sea ice. In Jokat, W. and H. Oerter, eds. The Expedition ANTARKTIS-XV of RV Polarstern in 1997: report of leg ANT-XIV/3. Bremerhaven, Alfred Wegener Institute for Polar and Marine Research, 18-30. (Report 267/96.)

Haas, C. and 10 others. 1999. Multidisciplinary ice tank study shedding new light on sea ice growth processes. EOS, $\mathbf{8 0}(43), 507,509,513$.

Helmke, E. and H. Weyland. 1995. Bacteria in sea ice and underlying water of the eastern Weddell Sea in midwinter. Mar. Ecol. Prog. Ser., 117(1-3), 269-287.

Herndl, G. J., G. Muller-Niklas and J. Frick. 1993. Major role of ultraviolet$\mathrm{B}$ in controlling bacterioplankton growth in the surface layer of the ocean. Nature, 361 (6414), 717-719.

Junge, K., C. Krembs, J.W. Deming, A. Stierle and H. Eicken. 2001. A microscopic approach to investigate bacteria under in situ conditions in sea-ice samples. Ann. Glaciol., 33 (see paper in this volume).

Kähler, P., P. K. Bjørnsen, K. Lochte and A. Antia. 1997. Dissolved organic matter and its utilization by bacteria during spring in the Southern Ocean. Deep-Sea Res., Ser. II, 44(1-2), 341-353.

Kattner, G. and H. Becker. 1991. Nutrients and organic nitrogenous compounds in the marginal ice zone of Fram Strait. 7. Mar. Syst., 2(3-4), 385-394.

Krembs, C. and A. Engel. 2001. Abundance and variability of microorganisms and TEP across the ice--water interface of melting first-year sea ice in the Laptev Sea (Arctic). Mar. Biol., 138(1), 173-185.

Kuosa, H., B. Norrman, K. Kivi and F. Brandini. 1992. Effects of Antarctic sea ice biota on seeding as studied in aquarium experiments. Polar Biol., 12(3-4), 333-339.

Lara, R. J. and G. Kattner. 1994. Humic substances in the nitrogen cycle of polar waters. A comparison between the Arctic and Antarctic. In Senesi, M. and T. M. Miano, eds. Humic substances in the global environment and implications on human health. Amsterdam, Elsevier Science B.V., 799804.

Leppäranta, M. and T. Manninen. Unpublished. The brine and gas content of sea ice, with attention to low salinities and high temperatures. Helsinki, Finnish Institute of Marine Research. (Internal Report 2.)

Melnikov, I. A. and G. L. Pavlov. 1978. Characteristics of organic carbon distribution in the waters and ice of the Arctic Basin. Oceanology, 18(1-2), 163-167.

Mopper, K., X. Zhou, R. J. Kieber, D. J. Kieber, R. J. Sikorski and R. D. Jones. 1991. Photochemical degradation of dissolved organic carbon and its impact on the ocean carbon cycle. Nature, 353(6339), 60-62.

Pakulski, J. D. and R. Benner. 1994. Abundance and distribution of carbo- 
hydrates in the ocean. Limnol. Oceanogr., 39(4), 930-940.

Palmisano, A. C. and D. L. Garrison. 1993. Microorganisms in Antarctic sea ice. In Friedmann, E. I., ed. Antarctic microbiology. New York, etc. Wiley-Liss Inc., 167-218.

Perovich, D. K. 1993. A theoretical model of ultraviolet light transmission through Antarctic sea ice. F. Geophys. Res., 98(C12), 22,579-22,587.

Porter, K. G. and Y. S. Feig. 1980. The use of DAPI for identifying and counting aquatic microflora. Limnol. Oceanogr., 25(5), 943-948.

Prézelin, B. B., M. A. Moline and H. A. Matlick. 1998. Icecolors'93: spectral UV radiation effects on Antarctic frazil ice algae. In Lizotte, M. P. and K. R. Arrigo, eds. Antarctic sea ice: biological processes, interactions and variability. Washington, DC, American Geophysical Union, 45-83. (Antarctic Research Series 73.)

Qian, J. and K. Mopper. 1996. Automated high-performance, high-temperature combustion total carbon analyzer. Anal. Chem., 68(18), 3090-3097.

Raymond, J. A., C.W. Sullivan and A. L. DeVries. 1994. Release of an iceactive substance by Antarctic sea ice diatoms. Polar Biol., 14(1), 71-75.

Smith, R. E. H., M. Gosselin, S. Kudoh, B. Robineau and S. Taguchi. 1997. DOC and its relationship to algae in bottom ice communities. 7. Mar. Syst., 11(1-2), 71-80.

Thomas, D. N. and M. Gleitz. 1993. Allocation of photoassimilated carbon into major algal metabolite fractions: variation between two diatom species isolated from the Weddell Sea (Antarctica). Polar Biol., 13(4), $281-286$.
Thomas, D. N., R. J. Lara, H. Eicken, G. Kattner and A. Skoog. 1995. Dissolved organic matter in Arctic multi-year sea ice during winter: major components and relationship to ice characteristics. Polar Biol., 15(7), 477-483.

Thomas, D. N. and 7 others. 1998. Biological soup within decaying summer sea ice in the Amundsen Sea, Antarctica. In Lizotte, M. P. and K. R. Arrigo, eds. Antarctic sea ice: biological processes, interactions and variability. Washington, DC, American Geophysical Union, 161-171. (Antarctic Research Series 73.)

Thomas, D. N., H. Kennedy, G. Kattner, D. Gerdes, C. Gough and G. S. Dieckmann. 2001. Biogeochemisty of platelet ice: influence on particle flux under land fast sea ice during summer at Drescher Inlet, Weddell Sea, Antarctica. Polar Biol. 24(7), 486-496.

Wedborg, M., M. Hoppema and A. Skoog. 1998. On the relationship between organic and inorganic carbon in the Weddell Sea. 7. Mar. Syst., $\mathbf{1 7}(1-4), 59-76$.

Weissenberger, J., G. Dieckmann, R. Gradinger and M. Spindler. 1992. Sea ice: a cast technique to examine and analyze brine pockets and channel structure. Limnol. Oceanogr., 37(1), 179-183.

Williams, P. J. LeB. 1995. Evidence for the seasonal accumulation of carbon rich dissolved organic material, its scale in comparison with changes in particulate material and the consequential effect on net $\mathrm{C} / \mathrm{N}$ assimilation ratios. Mar. Chem., 51(1), 17-29.

Williams, P. M. and E. R. M. Druffel. 1988. Dissolved organic matter in the ocean: comments on a controversy. Oceanogr. Mag., 1(1), 14-17. 